\title{
Suicidal ideation and attempt of older women in Northeastern Brazil
}

\author{
Ideação e tentativa de suicídio de mulheres idosas no nordeste do Brasil \\ Ideación e intento de suicidio de mujeres ancianas en el nordeste de Brasil
}

\section{Raimunda Magalhães da Silva', Girliani Silva de Sousa", Luiza Jane Eyre de Souza Vieira', José Manuel Peixoto Caldas', Maria Cecília de Souza Minayo"II}

\author{
' Universidade de Fortaleza. Fortaleza, Ceará, Brazil. \\ "Universidade Federal de Pernambuco. Recife, Pernambuco, Brazil. \\ II' Escola Nacional de Saúde Pública Sérgio Arouca. Rio de Janeiro, Brazil.
}

\begin{abstract}
How to cite this article:
Silva RM, Sousa GS, Vieira LJES, Caldas JMP, Minayo MCS. Suicidal ideation and attempt of older women in Northeastern Brazil. Rev Bras Enferm [Internet]. 2018;71(suppl 2):755-62. [Thematic Issue: Health of the Elderly] DOI: http://dx.doi.org/10.1590/0034-7167-2017-0413
\end{abstract}

\section{Submission: 06-26-2017 Approval: 10-26-2017}

\begin{abstract}
Objective: to associate the life experiences of older women from the Northeast of Brazil with their suicidal ideation and attempts. Method: Qualitative study with fourteen older adults from Piripiri (PI), Teresina (PI), Fortaleza (CE) and Recife (PE) who were interviewed between November 2013 and July 2014. The organization of data originated the themes: experiences of abuse throughout their lives; marital fractures and social isolation; weakened motherhood. Results: The women were born and lived most of their life in the countryside, amid poverty and social exclusion. They had a history of abuse, physical and sexual violence, perpetrated by intimate partners and/or family members. They experienced social isolation, weakened emotional bonds and several suicide attempts. Final considerations: The life of these older women was affected by traumatic events that enhanced feelings of hopelessness, depressive symptoms and the absence of a plan for the future, making them consider suicide as a way to anticipate death.
\end{abstract}

Descriptors: Suicide Attempt; Women; Older Adults; Suicidal Ideation; Violence.

\section{RESUMO}

Objetivo: analisar as experiências de vida de mulheres idosas nordestinas com ideação e tentativa de suicídio. Método: Estudo qualitativo com catorze idosas das cidades de Piripiri (PI), Teresina (PI), Fortaleza (CE) e Recife (PE) que foram entrevistadas entre novembro de 2013 e julho de 2014. A organização dos dados originou as temáticas: vivências de maus-tratos ao longo da vida; fraturas conjugais e isolamento social; e maternidade fragilizada. Resultados: As mulheres nasceram e viveram boa parte da vida na zona rural, na pobreza e exclusão social. Apresentavam histórias de maus-tratos, violência física e sexual, perpetrada por parceiros íntimos e/ou familiares. Vivenciaram isolamento social, vínculos afetivos fragilizados e várias tentativas de suicídio ao longo da vida. Considerações finais: A vida dessas idosas foi acometida por eventos traumáticos que aguçaram sentimentos de desesperança, sintomas depressivos e ausência de plano para o futuro, percebendo o suicídio como forma de antecipar a morte. Descritores: Tentativa de Suicídio; Mulheres; Idoso; Ideação Suicida; Violência.

\section{RESUMEN}

Objetivo: Analizar las experiencias de vida de mujeres ancianas nordestinas con ideación e intento de suicidio. Método: Estudio cualitativo con catorce ancianas de las ciudades de Piripiri (PI), Teresina (PI), Fortaleza (CE) y Recife (PE) que fueron entrevistadas entre noviembre del 2013 y julio del 2014. La organización de los datos originó las temáticas: vivencias de maltratos a lo largo de la vida; fracturas conyugales y aislamiento social; y maternidad frágil. Resultados: Las mujeres nacieron y vivieron buena parte de la vida en la zona rural, en la pobreza y exclusión social. Presentaban historias de maltratos, violencia física y sexual, perpetrada por parejas íntimas o familiares. Experimentaron aislamiento social, vínculos afectivos frágiles y varios intentos de suicidio a lo largo de la vida. Consideraciones finales: La vida de esas ancianas ha sido acometida por eventos 
traumáticos que agudizaron sentimientos de desesperanza, síntomas depresivos y ausencia de planes para el futuro, lo que las Ilevó a percibir el suicidio como forma de anticipar la muerte.

Descriptores: Intentos de Suicidio; Mujeres; Anciano; Ideación Suicida; Violencia.

CORRESPONDING AUTHOR Girliani Silva de Sousa E-mail: girlianis@gmail.com

\section{INTRODUCTION}

This work deals with the life experiences of older women with persistent suicidal ideation and behavior in Northeastern Brazil. It is understood that traumatic events which occurred in different stages of life - childhood, youth, adulthood and old age - mark in a negative way the path of the individual. In some cases, such experiences can lead him or her to develop suicidal ideation or attempts, associated in the literature with the following risk factors: family history of suicidal behavior; loneliness and social isolation; social, physical, mental or drug and alcoholism dependance; terminal illness accompanied by chronic pain; and social and economic problems, as well as mental strain ${ }^{(1-9)}$.

Suicide attempts are acts carried out by individuals seeking death, which, for various reasons, does not happen ${ }^{(10)}$. Such behavior usually happens when the individual fails to identify alternatives to solve their sufferings, seeing in death the solution to their problems.

It is known that older women attempt suicide more often than men ${ }^{(11)}$. The World Health Organization $(\mathrm{WHO})^{(12)}$ estimates that for every suicide consummated, twenty people attempt it. Among older adults ${ }^{(13)}$ it is relevant to note that the ratio between attempted and consummated suicides is approximately $2: 1$, considering that a prior attempt is an important predictive factor for future consummation. Despite their relevance, suicide attempts are underreported, seeing that of each three attempts, only one is considered to be an emergency, which occurs when the injury is too severe ${ }^{(14)}$. After an attempt, it is estimated that the risk of suicide increases in at least a hundred times in relation to the rates present in the general population ${ }^{(15)}$.

In Brazil, the Ministry of Health reports that 11 thousand people/year suicide themselves, a 5.7/100,000 inhabitants rate. The mortality from this cause is more prevalent in the population over 70 years old. Between 2011 and 2016, 27.8\% of self-harm was caused by suicide attempts and women attempted twice more than men. Poisoning constitutes one of the main methods used in suicide attempts ${ }^{(16)}$.

Women attempt suicide for reasons different from men. A number of factors are associated with this behavior, for example, physical, intrafamily, sexual and marital violence throughout their lives and in the present, physical ailments in childhood and in their older years, death of parents in childhood, financial difficulties ${ }^{(1-9)}$. Traumatic events such as abortion, postpartum depression and eating disorders, depression throughout their lives, social isolation, low resilience, lack of emotional control, death of spouse and children, social deprivation, family disputes and mental suffering also figure among these factors. Unlike men, marriage has not been a protective factor for older women ${ }^{(1-9)}$.
In Brazil, many older adults have committed suicide for believing that they had strictly fulfilled the gender role imposed on them by patriarchal society and that their life had no more meaning ${ }^{(3-5)}$. These women tend to experience social erasure and a feeling of being in a "non-place" after having exercised, exclusively, motherhood and household care ${ }^{(2-5,7)}$.

This article answers a very specific question: how did the life experiences of a few older women from Northeastern Brazil favor their suicidal behavior? This theme is developed from the narratives of their stories.

All around the world, self-inflicted deaths, suicidal ideation and attempts tend to grow among older people. In Brazil, the topic has been little discussed and investigated. Considering the increase in the elderly population, the importance of broadening and deepening the debate and the understanding of the phenomenon, addressing all regional and local singularities, is reaffirmed. According to the $\mathrm{WHO}^{(12)}$, suicide is a preventable event and, therefore, it is important to outline strategies that can detect situations that may lead to its ideation and attempts, calling out managers, health professionals and the society to act on behalf of an aging process endowed with quality of life and support by the family, friends and community. In this sense, discussing suicidal behaviors is simultaneously discussing life at a crucial stage of the existential cycle.

\section{OBJECTIVE}

To associate the life experiences of older women from the Northeast of Brazil with their suicidal ideation and attempts.

\section{METHOD}

\section{Ethical aspects}

The ethical procedures, with the reading and signing of the Informed Consent Form, were complied with according to resolution No. 466/2012 of the National Health Council and to the commitments made in the approval of this research.

\section{Type of study}

Study of qualitative nature ${ }^{(17)}$, in which we sought to understand the life experiences and underlying meanings assigned to them by the interviewed women ${ }^{(17)}$.

\section{Theoretical-methodological background}

A hermeneutical-dialectic approach was used ${ }^{(17)}$. In this way, the qualified and sensitive listening of the older women's narratives provided a way to apprehend the meaning of the experiences described, considering their opinions, values, beliefs and their way of thinking, feeling and acting ${ }^{(17)}$. The meaning of these facts of the past, associated with these women's desire to die, was sought for based on the present, and then projected towards the future. 


\section{Methodological Procedures}

\section{Study scenario}

This study is based on a national and multicentric research entitled Estudo sobre tentativas de suicídio em idosos sob a perspectiva da saúde pública ${ }^{(18)}$ [Study on suicide attempts by older adults from the perspective of public health] which involved twelve cities of the five macro-regions of Brazil. It relates to the experiences of suicide ideation and attempts of older women from the following cities of Northeastern Brazil - Teresina (PI), Piripiri, Piauí (PI), Recife (PE) and Fortaleza (CE) - which, in addition to high rates of suicide among older adults, are mostly known for featuring the greatest socio-economic and cultural inequalities in Brazil(19).

In this historical setting, gender discrimination persists, contributing to the devaluation of the role of women in society. Significant rates of hospitalization for attempted suicide (10.5 per 100,000 women) are found in the region, which have been increasing in recent years ${ }^{(20)}$.

\section{Data source}

The participants were located and contacted through the professionals of the Family Health Strategy (FHS), of the Center for Psychosocial Care (Caps) and of Long Permanence Institutes for Older Adults (Ilpi).

In this article, the experiences of fourteen older women with a history of suicidal ideation or attempt after 60 years of age, as reported by them, are analyzed.

\section{Data collection and organization}

The data was collected between November 2013 and July 2014. The in-depth interviews were based on a specific set of guidelines for interviews with older adults ${ }^{(21)}$, which included identification, demographic attributes, family configuration, morbidity, mental state prior to the suicidal ideation and attempt, possible causes, impact on the family, violence suffered and the possibility of overcoming the fact ${ }^{(5)}$.

The interviews were scheduled by the health professionals mentioned above and performed in the homes of the older adults (balcony, rooms, kitchen), considered by them to be a welcoming and private environment.

The first contact of one of the authors with the participants took place in their homes, with informal conversations and a relaxed atmosphere to ensure a relational environment that favored dialogue. Then, the interviewee was asked to speak spontaneously about her life and questions about the experience of suicidal attempts and ideation were made in a friendly manner, without judgment and criticism. Listening to their stories evoked strong feelings and, sometimes, resulted in crying. Where necessary, the older women were referred to competent professionals.

In this way, the interviews took place in a welcoming and harmonious atmosphere, with any possible constraints and disruptions having been avoided during the conversation, which lasted about 90 minutes. The recording of the interviews occurred after the signing the informed consent form.

\section{Data analysis}

After the material had been collected, the compilation and organization of a corpus of data was carried out to begin the pre-analysis, articulating the goal with the accounts of the older women. Upon careful reading, the cohesion between the stories of abuse in the various stages of the women's lives was identified, including disjunctions in marital and emotional relationships, strong feelings of abandonment and ambiguity in their roles as mothers.

From this logic, interpretative inferences resulted in the following themes: experiences of abuse throughout their lives; marital fractures and social isolation; weakened motherhood. The analysis and discussion focus on these points.

In spite of previous works being grounded on broader researches ${ }^{(5)}$, this article does not propose generalizations, but identifies the natural events that accompanied the life of these women who have experienced (or experience) suicidal ideation and attempt, a challenge to contemporary society.

\section{RESULTS}

Of the women interviewed who had experienced suicidal ideation and attempt, six were aged 60 to 69, five had between 70 and 79 years old and three had more than 80 years of age. Six had not completed elementary school, four were illiterate and four had completed high school. Of the total, eleven professed Catholicism; seven had more than five children; ten were widows and two were single. Nine lived in the house of relatives and five in their own homes. All had expressed suicidal ideation and twelve had attempted suicide by poisoning; seven had attempted suicide three or more times.

\section{Experiences of abuse throughout life}

Some of these older women had been experiencing difficult and adverse situations since childhood. They had dealt with their parent's death, experienced serious illnesses, lived with relatives who raped them, had a strict education in which they were "trained" to be housewives, mothers and wives, submissive to the will of men. The inequality of power between genders and the situations of violence experienced throughout their lives becomes evident:

\begin{abstract}
As a child I attempted suicide because my mother had spanked me for playing at the park, near those boats. She said that was a guy thing and beat me to a pulp. To get revenge I burned all my clothes and went to the backyard to pour kerosene on my body and set myself on fire. My friend called my mother and she started to cry thinking I was dead. (MAVS, 68 years old, married for 45 years, currently a retired housewife, Fortaleza/CE)
\end{abstract}

In the reports that follow, the older woman says that she had always felt alone in the world, and that the memories of her childhood relate to the death of her mother and abandonment by her father, who after marrying again, abdicated his paternal responsibility. She started being raised by an aunt. The situation of abandonment was worsened by the presence of constant physical and sexual violence inflicted on her by the family. She 
says she lived her childhood in constant exposure to violence, with psycho-emotional restlessness and hopelessness. She has no more expectations and plans to commit suicide:

I was a lassie, my brother-in-law used to touch me at night, and once, he beat me to a pulp, I didn't have lunch, nor dinner, I didn't eat and I was thinking: at six years old I lost my father, my mother, anyone could just slap me on the head, give me the belt, so while I'm still alive, I'm not getting spanked anymore. I started planning how to commit suicide, I picked up a razor and started cutting myself, then a neighbor saw it and took me to the emergency room. (MAON, 77 years old, widowed, not retired, lives in Ilpi, Fortaleza/CE)

Many have experienced misery and poverty and had to work as children to help pay the bills. This situation the abandonment of studies and childhood games as result, promoting frustrations and sadness.

I used to study at this school where the teacher would swat us, and I was terrified of that. She once thought I had hit a colleague and swatted me 6 times here [on the left hand] and 6 times here [on the right hand]. At 10 years old I started teaching there and this job helped me pay my tuition, since my mother couldn't. She was poor, my father was a bricklayer, they couldn't afford it, and we were six siblings in total. (MAVS, 68 years old, married for 45 years, currently a retired housewife, Fortaleza/CE)

The presence of depressive symptoms in childhood was also found in this study:

I've felt sad ever since I was little, my childhood was marked by this burden I bore, I was naughty and my mother had the right to spank me and that affected me a lot. (MAON, 77 years old, widowed, not retired, lives in Ilpi, Fortaleza/CE).

\section{Marital fractures and social isolation}

Early and arranged marriage was one of the most painful experiences reported by the various women interviewed. These women experienced resignation, sorrow, social deprivation and had to comply with their husbands' impositions, becoming hostages of household activities, of caring for their children or of the double burden conducted by obligation. For them, the world was a dark place devoid of rights, where they were trapped and crushed by the symbolic violence expressed by the culture of sexism.

The father of my children was a little difficult, he was very sexist, one of those people who say: "I don't want you stepping out of the door. You have no right to do anything, I'm the breadwinner here", he'd tap his pocket and say: "you get to eat whatever I want, I'm the one working". I thought I was too compliant, I felt as if I were a housemaid and we started fighting, sometimes he would beat me and we broke up because that was upsetting the children. (MELQ, 64 years old, widowed, currently unoccupied, Fortaleza/CE)

In the case mentioned above, in addition to the heartbreak, this older woman continued being psychologically abused so that she would not go to court and claim her rights, which meant she had to work hard to support her children:
I've done everything in this life, I used to sell fruits, vegetables, I would make cocada [coconut treat] for the boys to sell at school, I tried door-to-door selling, collecting recyclable waste. (MAVS, 68 years old, married for 45 years, currently a retired housewife, Fortaleza/CE)

Since she had to work night hours as well, she was also subjected to urban violence:

I was robbed many times when going home from work, the robbers would even assault me, beat me up, throw my glasses on the floor, slap my face. (MAVS, 68 years old, married for 45 years, currently a retired housewife, Fortaleza/CE)

Some of these women report having been brutally assaulted, made powerless and fragile in various stages of their lives. Some ran away from home, starved, slept on the streets and worked hard at undercompensated jobs to provide for their children. Those who attempted suicide at different stages of life, did so as a way of exterminating their suffering, which was constantly muffled, smothered and muted:

When all these thoughts start coming to me, I put the sheets in my mouth so that the neighbors won't hear it and I start crying, sobbing. (AAS, 66 years old, divorced, with a daughter, Fortaleza/CE)

\section{Weakened motherhood}

Motherhood is an event in which intense transformations occur in a woman's life. Helplessness, lack of emotional, social support and loneliness are stressful factors that led some of the women interviewed to develop postpartum depression and suicidal behavior:

Soon after I got married, we moved and I had post-partum depression, I was alone, having to take care of a baby, taking care of a house, without knowing anyone, I felt really lonely. There was no one and I didn't know to care for the girl, I started getting desperate, you know? I drank poison and almost gave it to her as well. (MGAA, 63 years old, widowed with four children, TERESINA/PI)

The narrative evidences the anguish that motherhood exercised in this woman's life. The distress of not knowing how to deal with a newborn baby caused the collapse of her emotional life. The desperate situation highlights the lack of support in facing the difficulty of complying with the social role of mother, wife and housekeeper.

In motherhood, the postpartum moments are not necessarily the most delicate. In general, the interviewed women who had children fully dedicated their lives to caring for them. Many faced enormous obstacles to raise and educate them. However, they complain of lack of reciprocity, of feeling abandoned, neglected and unfortunate.

If it was up to me I wouldn't get up from bed at any moment, sometimes my children won't come visit me for three months or more [...] in this regard I have much to regret, she [the 
daughter] says "mom, everybody works late into the night," this is what upsets me the most: the coldness I find in my children, it pains me, it does me a lot of harm, it hurts me a lot. (LCS, 87 years old, widowed, four children, Piripiri/PI)

This older woman comments that she has always done everything for her children and throughout their whole lives she has treated them with zeal, love and respect. But nowadays they seek her only when they need money. This neglect and disregard, regarded as ingratitude, is not an isolated case, but a frequent reason older people consider suicide, according to these two women:

I attempted suicide by hanging myself, I was lucky I didn't die, but I never told them, because I think there wouldn't be much sadness, nor a lot of crying, they'd say: she was 80 years old and wanted to leave this earth. (LCS, 87 years old, widowed, four children, Piripiri/PI)

My daughters are sometimes rude with me, it's upsetting; [...] They help me a lot, but, for me, showing love, affection, taking care of me is more important than any financial aid, they mean the world to me. What's the use of having money, but when things get rough, having no one to turn to? (MAPS, 71 years old, female, widowed, six children, Recife/PE)

The anticipation that their death would be celebrated with some relief by the families is certainly the best evidence of the feeling of loneliness and isolation experienced by the many women who perceive themselves as "a burden" to their children. And their narratives are often a plead for reciprocity. One of them reports having had to work to pay for her children's studies, assuming a double burden, for she had to do all the housework and in the evening, devote her time to educate and care for them. While crying, she reaffirms what has already been mentioned: that her children do not understand her, that they do not understand that while aging, one wants nothing but to lead a quiet life surrounded by affection.

\section{DISCUSSION}

The literature shows that widowed, separated or divorced women, with low level of education and living with others, attempt suicide more often ${ }^{(2-5,8-9,22-26)}$ and by less violent means when compared to men ${ }^{(2-5,14,26)}$. However, the number of attempted suicides among elderly women is higher than among older men ${ }^{(6,11-13,24)}$.

The findings show that the use of physical force to scold a child for not behaving like a girl is manifested in the consent to the denial of the self which, at the time, was at the center of female education, resulting in situations of vulnerability to suicide. The heteronormative construction established in the toys that belong to the male and female genders, the ways of dressing and behaving were, and in many cases remain as, ways to define and limit the role of women within society ${ }^{(2-3,27)}$.

Beauvoir (28) argues that "no biological, psychochological, or economic fate determines the figure that the human female presents in society", which defines the gender of every human being. Society constructs the representation of what is supposed to be female and male, thus, women erase from themselves the faint prints of their steps in this world ${ }^{(3,28-29)}$. This act of self-destruction is also a way to consent to the silence that society imposes on women ${ }^{(28-29)}$.

The older women of this study were born and lived much of their life in the rural region, where they were raised and socialized in a more conservative and rigid manner than in the cities ${ }^{(2-5)}$. In addition to the fact of them living in isolated places, many came from poor backgrounds, leading them to experience deprivation and social exclusion.

In the 1940s and 1950s, the Northeast region, especially in rural areas, had intense social and economic inequalities - much greater than those which still remain - due to the high concentration of income of large landowners and to the natural phenomenon of constant drought in the sertão region. Given this reality, the health conditions were precarious, many women died in childbirth or from causes related to it, and those who survived and had numerous children relied on the financial help from family members ${ }^{(30)}$. In some families, the relatives assumed the responsibility to raise and educate children as if they were their own.

Suicide attempts and consummation in childhood are, in general, impulsive acts, but it evidences how these older women had to experience their pain alone, in complete helplessness. Some say they were devalued and disrespected as children, disillusioned with life and with no hope of having a better future. It is known that women who were sexually abused in childhood attempt suicide more often throughout life in relation to the general population ${ }^{(1-2,5,9,14)}$.

The position of inferiority conferred to women and the absence of social space contribute so that sexual violence is silenced in relation to sexual and reproductive rights. Vulnerable, the older women who have attempted suicide talk about the lack of inner strength to speak up and about the situations of intense suffering that can result in suicidal behavior and in self-inflicted death.

Emotional problems that arise from a life of poverty and misery and the suppressing of their plans for the future undermine these women's strength to live. Many of the interviewees attempted suicide due to existential traumatic events that still affect them to this day.

Goldney(31) notes that traumatic experiences in childhood are predisposing factors for suicidal behavior, as in the case of stress experienced by the death of one's parents in this stage of life, the constant bickering between one's parents, the tension in the parent's relationship with the children and the perception of bad physical health.

Unlike Goldney's study(31), this research did not find association between perceiving one's physical health as bad with stress in childhood. However, the tension in the relationship with one's mother and the presence of violence as a way to educate were found to be, as in the said study, triggers for symptoms of depression.

What can be inferred from the results is that some of the researched women had a life filled with void spaces of affection filled by a sort of loneliness ${ }^{(2-9,32-36)}$ that kills the joy of living. 
The worst in loneliness is not being alone, it is the feeling of not having anyone to turn to, except for when submitting themselves to being a man's mere possession and object ${ }^{(28,37)}$.

A bibliometric study on gender violence pointed out that women are the main victims of conjugal violence, and their intimate partners are the main aggressors ${ }^{(38)}$. Being abused by an intimate partner is a significant risk factor for women's suicidal ideation and attempts. This situation can be worsened by the lack of social and psychological support, for triggering anxiety, sadness and hopelessness and a sense of impotence, resulting in depression ${ }^{(7-8,32-35)}$. The literature $\mathrm{e}^{(1,3-5,8-9,34-35)}$ shows its negative impacts on the mental health of women who have suffered psychological violence, highlighting the difficulty of recovery.

An anthropological study ${ }^{(25)}$ shows that it is not unusual for women who have been raped by intimate partners to seek suicide as a solution to their problems and, in addition to the selfdestructive act, cause the death of their small children as a way to avoid their future suffering. This work corroborates at least one statement given by the interviewed older women: "I drank poison and almost gave it to her [newborn daughter] as well".

In some places, like the countryside of China, the suicide of married women is considered an act of rebellion and revenge against the abusive relationship with their husband ${ }^{(37)}$. In the region of Papua New Guinea, women who committed suicide had written letters describing the situations of violence they had suffered, as a way to get revenge on their abusive husbands and expose the abuse ${ }^{(25)}$.

In Brazil, Meneghel ${ }^{(5)}$ argues that suicide attempts among women, whether triggered by their husbands leaving them, cheating on them or by them feeling like their life has lost meaning, are accompanied by the weight of guilt. This guilt results from the rigidity of a patriarchal culture that induces accommodation and alienation of the sense of being, endorsing feelings of emptiness and helplessness. In Northeastern Brazil, this kind of culture is still very present, consecrating the hierarchical relationships of gender in which the male role is characterized by violence and female submission ${ }^{(3-5,7,28)}$. But this problem is not regional only, because in Brazil, more than half of the women who have been victims of violence have not asked for help. And, despite the validity of the Maria da Penha Law, which seeks to prevent domestic and family violence against women, there has been no impact on the annual mortality rates, in comparison to the periods before the validity of the law ${ }^{(30)}$.

Women subjected to violence seek other strategies to change the situation before resorting to suicide. Despite remaining in circumstances of passivity, many assume confrontation behaviors and look for support among relatives and other women ${ }^{(25)}$. That was not the case of the interviewees in this study, who experienced a historical period dominated by patriarchy, going through a socialization process focused on submission and under the strong rule of male violence. Even so, some were able to break the chains of marriage and take control of their lives. However, they found themselves alone, isolated, discriminated and subjected to intense social destitution and psychological suffering.

It can be said that the structural situations contributed to increase their psychological suffering and affected their capacity of mental reorganization to confront and overcome the stressful factors in their lives. Several older women reported becoming more nervous, more agitated, sadder and lacking the will to live due to the recurrence of violence. Some, despite being at the end of their lives, have been diagnosed with depression, schizophrenia and anxiety disorder. However, the vast majority has not received any type of psychological and psychiatric support.

A study conducted in Hong Kong ${ }^{(39)}$ also notes that women with postpartum depression feel hopelessness, helplessness and loss of control over their lives. Their unhappiness is associated with lack of affection and collaboration from their partners, leading them to despair and suicide. However, in general, these women are not able to verbalize their distress and seek help.

The fading of emotional relationships and the negligence on the part of their children have an assertive character in these women's suicide attempts ${ }^{(3-6,33)}$, manifesting itself in oftentimes intense psychological suffering ${ }^{(36)}$, corroborating Canetto's argument ${ }^{(40)}$ according to which suicidal behavior in women is determined by interpersonal reasons more than by the desire to die. Similarly, studies conducted in Korea ${ }^{(8)}$ and in Australia ${ }^{(36)}$ found that older women who had considered or attempted suicide reported higher levels of anxiety, distress, lower capacity of resilience and personal and interpersonal control. People with low resilience have lower capacity to deal with stressful events in life and greater difficulty to overcome them ${ }^{(35,39)}$. Women with neuroticism ${ }^{(25)}$ and lifelong depression attempt suicide more often ${ }^{(4,7-8,25,33)}$.

The psychic suffering shown at the end of life for all of the women interviewed is the culmination of emotional losses that occurred throughout their existence, such as the death of parents and spouse, loss of autonomy to decide the course of their lives, social deprivation, loss of their homes and possessions when they become widows and have to begin living with their children or in long-stay institutions, among other vicissitudes. This sorrow increases as they start to face the limitations of aging, suffer patrimonial violence and become socially and physically dependent, strongly affecting their feeling of dignity.

\section{Limitations of study}

It is important to remember that some limitations of this study may relate to the limited number of participants by cities analyzed, justified by the difficulty in locating them, as well as to the legitimized silence around the phenomenon; the underreporting of cases of suicide attempts is a Brazilian reality, which contributes to keeping them invisible.

\section{Contributions to the area of nursing and public health}

Nursing care practices should be aimed at the early detection of the risk of suicide and the proper handling of older women who have attempted suicide. In this scenario, it is considered essential that interventions seek to increase the quality of life in old age, increasing the value of human life, which requires that these professionals provide a qualified and humanized care, with solidarity and mutual support. This is made possible through the understanding of the older person within their historical and cultural context, including their feelings, questions and reflections on the experiences of growing old. 


\section{FINAL CONSIDERATIONS}

It was noted that women living in poverty, with low educational level or illiterate, are those who have suffered the most violence. In these cases, the abuse began in childhood, was extended to the phase of sexual initiation and continued with marriage and in the exercise of motherhood.

Most of the interviewees who have considered or attempted suicide had been raped by an intimate partner or family, lost their autonomy in old age, along with significant bonds, social references and emotional belongings that had been acquired with sacrifice, during the course of their lives. Many experienced or experience chronic situations of physical, domestic, sexual and psychological violence usually perpetrated by friends and family members; some experienced postpartum depression and all find themselves in a state of loneliness and social isolation that is expressed in depressive symptoms.

Although their suicidal behavior may have other causes, it is explained through narratives of family disputes, gender oppression, social devaluation and tiredness with the "meaningless" life they lead because its lost value for the people closest and dearest to them.

It is also clear that the patriarchal and male-dominated values rooted in the Northeastern culture are largely responsible for these women's social, cultural, educational and work limitations, erasing their dreams and life projects.

\section{REFERENCES}

1. Devries K, Watts C, Yoshihama M, Kiss L, Schraiber LB. Violence against women is strongly associated with suicide attempts: evidence from the WHO multi-country study on women's health and domestic violence against women. Soc Sci Med [Internet]. 2011 [cited 2017 May 23];73(1):79-86. Available from: https://www.ncbi.nlm.nih.gov/pubmed/21676510

2. Beautrais AL. Women and suicidal behavior. Crisis[Internet]. 2006[cited 2017 May 23];27(4):153-6. Available from: https://doi. org/10.1027/0227-5910.27.4.153

3. Meneghel SN, Gutierrez DMD, Silva RM, Grubits S, Hesler LZ, Ceccon RF. Suicídio de idosos sob a perspectiva de gênero. Ciênc Saúde Colet[Internet]. 2012[cited 2017 May 23];17(8):1983-92. Available from: www.scielo.br/pdf/csc/v17n8/09.pdf

4. Minayo MCS, Cavalcante FG. Estudo compreensivo sobre suicídio de mulheres idosas de sete cidades brasileiras. Cad Saúde Pública[Internet]. 2013[cited 2017 May 23];29(12):2405-15. Available from: http://www.scielo.br/pdf/csp/v29n12/v29n12a06. pdf

5. Meneghel SH, Moura R, Hesler LZ, Gutierrez DMD. Tentativa de suicídio em mulheres idosas: uma perspectiva de gênero. Ciênc Saúde Colet[Internet]. 2015[cited 2017 May 23];20(6):1721-30. Available from: www.scielo.br/pdf/csc/v20n6/1413-8123csc-20-06-1721.pdf

6. Minayo MCS, Cavalcante FG. Suicide attempts among the elderly: a review of the literature (2002/2013). Ciênc Saúde Colet[Internet]. 2015[cited 2017 May 23];20(6):1751-62. Available from: www.ncbi.nlm.nih.gov/pubmed/26060953

7. Cavalcante FG, Minayo MCS, Mangas RMNM. Diferentes faces da depressão no suicídio de idosos. Ciênc Saúde Colet[Internet]. 2013[cited 2017 May 23];18(10):2985-94. Available from: www.scielo.br/pdf/csc/v18n10/v18n10a23.pdf

8. Park GR, Park EJ, Jun J, Kim NS. Association between intimate partner violence and mental health among Korean married women. Public Health[Internet]. 2017[cited 2017 Oct 07];152:86-94. Available from: http://dx.doi.org/10.1016/j.puhe.2017.07.023

9. Bebbington PE, Cooper C, Minot S, Brugha TS, Jenkins R, Meltzer H, et al. Suicide attempts, gender, and sexual abuse: data from the 2000 British Psychiatric Morbidity Survey. Am J Psychiatry[Internet]. 2009[cited 2017 May 23];166:1135-40. Available from: www.ncbi.nlm.nih.gov/pubmed/19723788

10. Durkheim E. O Suicídio. $3^{\text {a }}$ ed. Lisboa: Editorial Presença; 1982.

11. Conwell, Y. Suicide in later life: challenges and priorities for prevention. Am J Prev Med[Internet]. 2014 [cited 2017 May 23];47(3S2):244-50. Available from: www.ncbi.nlm.nih.gov/pubmed/25145746

12. Organización Mundial de la Salud. OMS. Prevención del suicidio: un imperativo global[Internet]. Washington: OMS; 2014 [cited 2017 May 23]. Available from: www.who.int/mental_health/suicide-prevention/es/

13. De Leo D, Padoani W, Scocco P, Lie D, Bille-Brahe U, Arensman E, et al. Attempted and completed suicide in older subjects: results from the WHO/EURO Multicentre Study of Suicidal Behaviour. Int J Geriatr Psychiatry[Internet]. 2001[cited 2017 May 23];16(3):300-10. Available from: https://www.ncbi.nlm.nih.gov/pubmed/11288165

14. Botega JN, Marín-Leon L, Oliveira HB, Barros MBA, Silva VF, Dalgalarrondo P. Prevalências de ideação, plano e tentativa de suicídio: um inquérito de base populacional em Campinas, São Paulo, Brasil. Cad Saúde Pública[Internet]. 2009[cited 2017 May 23];25(12):2632-8. Available from: http://www.scielo.br/pdf/csp/v25n12/10.pdf

15. Owens D, Horrocks J, House A. Fatal and nonfatal repetition of self-harm. Systematic review. Br J Psychiatry[Internet]. 2002[cited 2017 May 23];181:193-9. Available from: https://www.ncbi.nlm.nih.gov/pubmed/12204922

16. Brasil. Ministério da Saúde. Agenda Estratégica de Prevenção do Suicídio: sistema de informação de mortalidade[Internet]. 2017[cited 2017 Oct 07]. Available from: http://portalarquivos.saude.gov.br/images/pdf/2017/setembro/21/Coletiva-suicidio-21-09.pdf 
17. Minayo MCS. O desafio do conhecimento: pesquisa qualitativa em saúde. 14ª ed. Rio de Janeiro: Hucitec; 2014.

18. Minayo MCS, Cavalcante FG, Figueiredo AE, Mangas RM. Estudo sobre tentativas de suicídio em idoso sob a perspectiva da saúde pública [Projeto de Pesquisa]. Rio de Janeiro: Fiocruz; 2013.

19. Pinto LW, Assis SG. Descriptive study of suicide attempts in the Brazilian elderly population, 2000-2014. Ciênc Saúde Colet[Internet]. 2015[cited 2017 Jun 10];20(6):1681-92. Available from: www.ncbi.nlm.nih.gov/pubmed/26060946

20. Organização Mundial de Saúde. Estado das cidades do mundo unindo o urbano dividido[Internet]. 2010 [cited 2017 Jun 10]. Available from: http://www.ipea.gov.br/agencia/images/stories/PDFs/100408_cidadesdomundo_portugues.pdf

21. Cavalcante FG, Minayo MCS, Gutierrez DMD, Sousa GS, Silva RM, Moura R, et al. Tools, strategies and qualitative approach in relation to suicidal attempts and ideation in the elderly. Ciênc Saúde Colet[Internet]. 2015[cited 2017 Jun 10];20(6):1667-80. Available from: https://www.ncbi.nlm.nih.gov/pubmed/26060945

22. Chan SMS, Chiu FKH, Lam CWL, Wong SMC, Conwell, Y. A multidimensional risk factor model for suicide attempts in later life. Neuropsychiatr Dis Treat [Internet]. 2014[cited 2017 Jun 10];10:1807-17. Available from: www.ncbi.nlm.nih.gov/ pubmed/25258538

23. Beautrais AL. A case control study of suicide and attempted suicide in older adults. Suicide Life Threat Behav [Internet]. 2002[cited 2017 Jun 10];32(1):1-9. Available from: www.ncbi.nlm.nih.gov/pubmed/11931007

24. Kjolseth I, Ekeberg O, Steihaug S. Why do they become vulnerable when faced with the challenges of old age? Elderly people who committed suicide, described by those who knew them. Int Psychogeriatr [Internet]. 2009 [cited 2017 Jun 10];21:903-912. Available from: www.ncbi.nlm.nih.gov/pubmed/19519985

25. Counts DA. Female suicide and wife abuse: a cross-cultural perspective. Suicide Life Threat Behav [Internet]. 1987 [cited 2017 Jun 10];17(3):194-204. Available from: www.ncbi.nlm.nih.gov/pubmed/3686620

26. Denning DG, Conwell Y, King D, Cox C. Method Choice, Intent, and Gender in Completed Suicide. Suicide Life Threat Behav [Internet]. 2000[cited 2017 Jun 10];30(3):282-8. Available from: https://www.ncbi.nlm.nih.gov/pubmed/11079640

27. Brilhante AVM, Moreira GAR, Vieira LJES, Silva RM, Catrib AMF. The "northeastern male" in formative years: sexuality and gender relations among teenagers. Rev Bras Promoç Saúde [Internet]. 2015[cited 2017 Jun 10];28(4):471-8. Available from: http://ojs. unifor.br/index.php/RBPS/article/viewFile/3835/pdf_1

28. Beauvoir S. O segundo sexo. São Paulo: Difusão Européia do Livro; 1970.

29. Perrot M. As mulheres ou os silêncios da história. $1^{\text {a }}$ ed. Bauru: Edusc, 2005.

30. Gomes, GM. Velhas secas em novos sertões: continuidade e mudanças na economia do semi-árido e dos cerrados nordestinos. Brasília: IPEA, 2001.

31. Goldney, RD. Parental loss and reported childhood stress in young women who attempt suicide. Acta Psychiat Scand [Internet]. 1981[cited 2017 Jun 10];64:34-39. Available from: https://www.ncbi.nlm.nih.gov/pubmed/7315493

32. Silva RS, Mangas RMN, Figueiredo AEB, Vieira LJES, Sousa GS, Cavalcanti AMTS, et al. The influence of family problems and conflicts on suicidal ideation and suicide attempts in elderly people. Ciênc Saúde Colet [Internet]. 2015[cited 2017 Jun 10];20(6):1703-10. Available from: http://www.scielosp.org/pdf/csc/v20n6/en_1413-8123-csc-20-06-1703.pdf

33. Cook JM, Pearson JL, Thompson R, Black BS, Rabins PV. Suicidality in older African Americans: findings from the EPOCH study. Am J Geriatr Psychiatry [Internet]. 2002[cited 2017 Jun 10];10(4):437-46. Available from: https://www.ncbi.nlm.nih.gov/ pubmed/12095903

34. McLaughlin LJ, O'Carroll RE, O'Connor RC. Intimate partner abuse and suicidality: a systematic review. Clin Psychol Rev [Internet]. 2012[cited 2017 Jun 10];32(8):677-89. Available from: www.ncbi.nlm.nih.gov/pubmed/23017498

35. Florez IA, Allbaugh LJ, Harris CE, Schwartz AC, Kaslow NJ. Suicidal ideation and hopelessness in PTSD: spiritual well-being mediates outcomes over time. Anxiety Stress Coping[Internet]. 2017[cited 2017 Oct 07];28:1-13. Available from: http://dx.doi.or g/10.1080/10615806.2017.1369260

36. Lau R, Morse CA, Macfarlane S. Psychological factors among elderly women with suicidal intentions or attempts to suicide: a controlled comparison. J Women Aging [Internet]. 2010[cited 2017 Jun 10];22(1):3-14. Available from: www.ncbi.nlm.nih.gov/ pubmed/20391144

37. Bourdieu P. A dominação masculina. $2^{\text {a }}$ ed. Rio de Janeiro: Bertrand do Brasil; 2002.

38. Brilhante AVM, Moreira GAR, Vieira LJES, Catrib AMF. Um estudo bibliométrico sobre a violência de gênero. Saúde Soc [Internet]. 2016[cited 2017 Jun 10];25(3):703-15. Available from: http://www.scielo.br/pdf/sausoc/v25n3/1984-0470-sausoc-25-03-00703.pdf

39. Chan SMS, Levy V, Chung TKH, Lee D. A qualitative study of the experiences of a group of Hong Kong Chinese women diagnosed with postnatal depression. J Adv Nurs[Internet] 2002[cited 2017 Jun 10];39(6):571-9. Available from: www.ncbi.nlm.nih.gov/ pubmed/12207755

40. Canetto S. Women and Suicidal Behavior: a cultural analysis. Am J Orthopsychiatry [Internet]. 2008[cited 2017 Jun 10];78(2):25966. Available from: https://www.ncbi.nlm.nih.gov/pubmed/18954189 